\title{
Economic Value of Forest Hydrological Benefit of Musi Watershed: Case of Perapau Sub Watershed, Indonesia
}

\author{
Nur Arifatul Ulya ${ }^{1 *}$, Adi Kunarso ${ }^{1}$, Efendi Agus Waluyo ${ }^{1}$, Tubagus Angga Anugrah \\ Syabana ${ }^{1}$, Andree Ekadinata ${ }^{2}$ \\ ${ }^{1}$ Environment and Forestry Research and Development Institute of Palembang, Indonesia \\ ${ }^{2}$ World Agroforestry Centre, Bogor, Indonesia
}

Received: 2018-10-20 Accepted: 2019-03-13

\section{Keywords:}

water for household; water for agriculture procurement cost; Semende.

Corespondent Email: nurarifatululya@gmail.com

\begin{abstract}
Forest area in upper Perapau subwatershed that provides a hydrological benefit for community living surrounding is now partially converted to plantations, dryland farms and paddy fields, whereas the forests are part of protected forest and wildlife reserve. The land cover change occurs due to lack of understanding about the economic value of hydrological benefits of forests in the Perapau subwatershed. This study aims to determine the economic value of hydrological benefits of forests in Perapau subwatershed. Procurement cost method used to estimate the economic value of the hydrological benefits of the Perapau sub watershed. The economic value of hydrological benefits for household and agricultural purposes is 128.905 million USD and 832,187 USD. Based on the economic value of hydrological benefits, sustainability of forest in the upstream of Perapau subwatershed must be supported for sustainability of hydrological services of a watershed.
\end{abstract}

\section{Introduction}

Forest ecosystems provide many significant benefits for human life. These benefits are derived from ecological processes that either directly or indirectly contribute to human well-being (Costanza et al., 1998, 2011; Millennium Ecosystem Assessment, 2005). Benefits provided by forests are presented in terms of the total economic value of forest resources (Adger, Brown, Cervigni, \& Moran, 2010; Admiraal, Wossink, de Groot, \& de Snoo, 2013; Groot \& Meer, 2010; Munasinghe, 1992). The total economic value is an expression of the total value of benefits derived from a natural resource, including forest resources, that expressed in the monetary framework (Bateman, Mace, Fezzi, Atkinson, \& Turner, 2011).

Benefits of forest resources regarding of Total Economic Value (TEV) are divided into two major groups, namely, use value and non-use value. Use value consists of direct use value, indirect use value, and option value. Direct use value is also known as extractive, consumptive, in the form of utilization of goods and services that can be extracted, consumed directly from the forest. Indirect use values are consist of goods and services produced by forests due to the existence of forest ecosystems. Indirect use values originate from ecological processes that continuously provide benefits to people and ecosystems in the world, such as carbon sequestration and global climate change (Adger et al., 2010; Admiraal et al., 2013; Groot \& Meer, 2010; Munasinghe, 1992).

Non-use value comes from benefits provided by the forest when not in use. Non-use values may consist of option value, bequest value and existence value. The option value is the potential direct or indirect benefits of forest resources that can be utilized in the future, assuming that the resources are not damaged or permanently damaged. The heritage value is given by the community at this time in the remaining forest area (natural heritage) to be inherited for future generations. The existence value is the value that comes from the existence of the forest, related to spiritual values, aesthetics and cultural benefits (Adger, Brown, Cervigni, \& Moran, 2010; Admiraal, Wossink, de Groot, \& de Snoo, 2013; Groot \& Meer, 2010; Munavsinghe, 1992). Cultural services consist of aesthetics information, recreation, information and culture art, spiritual experience and cognitive development(Groot et al., 2012). Cultural services that were more specific to local demands consist of recreational hunting, local ecological knowledge, and local identity, while cultural services demanded by beneficiaries on broader scales are environmental education, and scientific knowledge (Zorrilla-Miras et al., 2014). The esthetic value of forest area attractive scenery including sights, smells, and sounds. The spiritual value of forest consists of sacred, religious, or spiritually special places, reverence, and respect for nature (Brown, 2013).

The diverse benefits provided by forest ecosystems indicates the importance of the role of forests for human life. Water is one of the most important benefits for human life that come from forests. Upper watersheds have an important role in the hydrological cycle (Costanza et al., 1998, 2011; Ulya, Warsito, Andayani, 
\& Gunawan, 2014). Forests retain rainwater, absorb into the soil and regularly release through the surface and subsurface water flows, so that the benefits are more perceived by other ecosystems and have broad socioeconomic impacts (Brookhuis \& Hein, 2016; Carvalho-Santos, Honrado, \& Hein, 2014; Widada \& Darusman, 2004).

People in the upper watershed use water primarily for household use and agricultural irrigation. Water that flows from the forests in upstream watersheds is also used as turbine for micro hydropower plants (MHP) and hydroelectric power plants (Brauman, Daily, Duarte, \& Mooney, 2007; Kaldellis, 2007; Murni, Whale, Urmee, Davis, \& Harries, 2012; Raman, Hussein, \& Palanisamy, 2009). Water is also used as a major means of a transportation system, both in upper and the lower watershed (Ulya et al., 2014).

People in Perapau subwatershed use water for household needs and irrigate rice fields. At the present time, upstream forest conditions of the Perapau subwatershed are deforested, partly transformed into plantations, mixed farmland, and rice fields. A continuous land cover change will lead to a decrease in the role of forests in the hydrological cycle. This condition will threaten the water supply, whereas water is essential for human well-being (Brookhuis \& Hein, 2016; Carvalho-Santos et al., 2014). Activities that lead to changes in forest cover are other uses (e.g., plantation, dryland farms, paddy fields) are driven by socioeconomic factors (Dwiprabowo, Djaenudin, Alviya, \& Wicaksono, 2014; Kaimowitz \& Angelsen, 1998).

Forest areas in the upper Perapau subwatershed are economics resource that scarce and necessary. Currently, the forest resources are confronted with encroachment for plantation and agriculture. Forest resources that scarce and necessary can provide benefits according to their capacity through efficient resources allocations. The market is the best allocating tool for scarce resources. Therefore, information on the market price of those resources is required (Hanley, Shogren, \& White, 2013; Hufschmidt, David E. James, Meister, Bower, \& Dixon, 1983; Schaafsma et al., 2014). While Bateman et al., (2011) state the use of monetary value as a measure of resource scarcity, reflected by the economic value of the resource.

This study aims to determine the economic value of hydrological benefits of forests in the Perapau subwatershed. The results of this research are expected to be used as justification for forest management in upper watershed which currently experience conversion.

\section{Methods}

\section{Research Scope}

The research is a case study conducted in Perapau subwatershed, one of the sub-watersheds in the upper Musi watershed. The hydrological benefit values to be discussed in this research include the value of water for household and agriculture purpose. Water consumption for the household to be measured is water used by communities for drinking, cooking, washing, bathing, and also for latrines. Meanwhile, water consumption for agriculture is water allocated to irrigate paddy fields.

\section{Location and Time of Study The Study Area}

The research has been was conducted in Perapau subwatershed that administratively located in Semende Darat Laut Sub District, Muara Enim District, South Sumatra Province. The data was collected in four villages which are located within the subwatershed

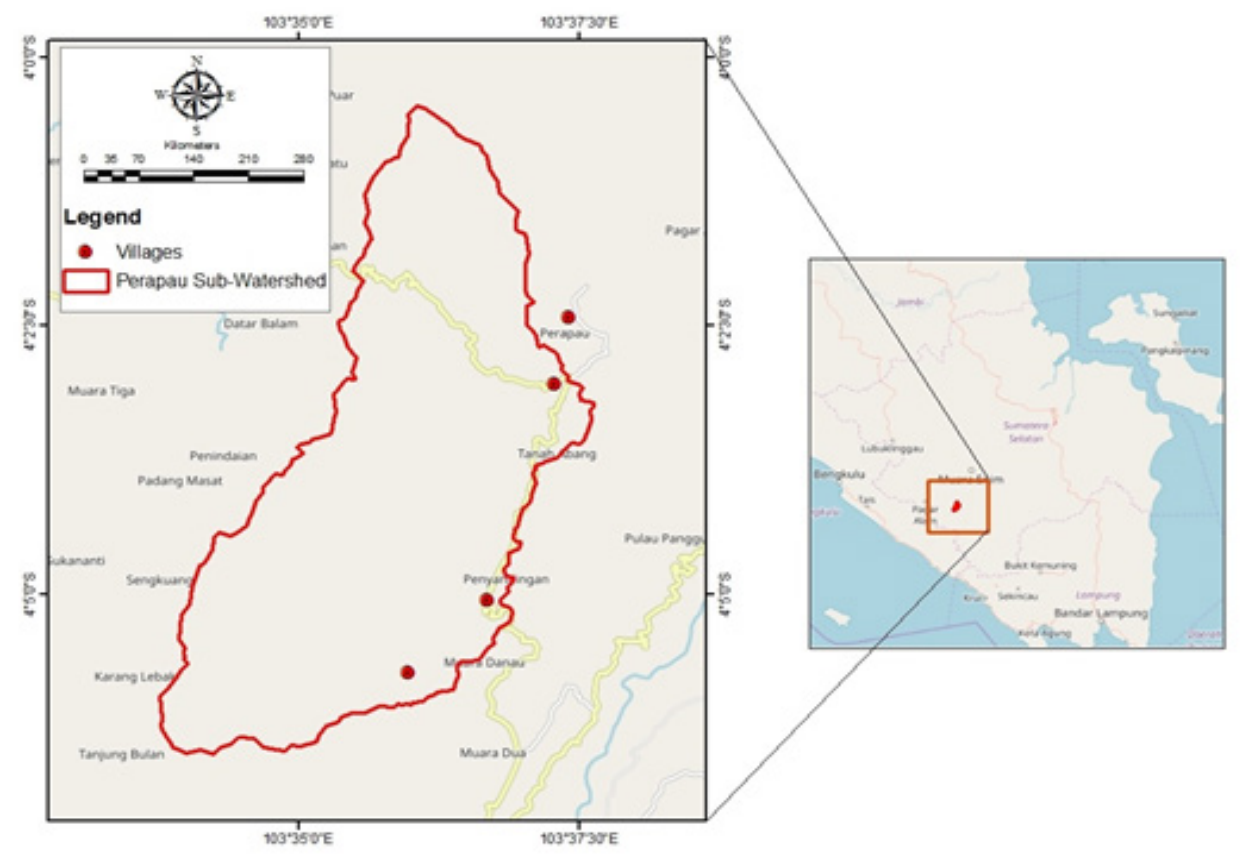

Figure 1. The study area 
(Muara Danau village, Penyandingan village, Tanah Abang village and Perapau village). The map of research location area is presented in Figure 1.

The research location was selected by using purposively method. The sample was selected by considering the communities in those four villages depend on water from Perapau watershed to fulfill their need both for household and agricultural purpose. Meanwhile, forests in upper subwatershed are experiencing threats of conversion for plantations and agriculture. Generally, forest conversion into plantation becomes the main issue in the upper watershed of Musi River. The research was conducted from October to December 2016. The research was carried out during the month as farmers were in the village to grow rice, making it easy to meet with farmers and key persons as well as observations of water utilization both for household and agricultural purposes.

\section{Data Collection}

Research data were obtained through survey of a biophysical survey, a household survey using questionnaire, in-depth interview and focus group discussion (FGD). The respondents (30 respondents per village) were randomly selected, represented by household heads that using water from Perapau Subwatershed. In-depth interviews were conducted with key persons that consist of traditional leaders, representative of water management institutions and representative of forest farmer groups. The key persons were chosen with the assumption that they had an understanding about the history of water management in the village starting from traditional water management by traditional leaders to the current condition (WSLIC/Water Supply and Sanitation Project for Low Income Community by Ministry of Health ) projects, and PAMSIMAS/water pipe system built by Local Government). To obtain reliable data and information, an FGD was then carried out involving key persons (Singarimbun \& Effendi, 2008). The data collected includes the biophysical characteristics of Perapau subwatershed, village monograph data, socioeconomic data, and access of communities to water and watershed. The biophysical characteristics data consist of a land cover, soil, and climate data. It was analyzed to determine the characteristics of subwatershed.

Land cover data was obtained through satellite imagery interpretation. Soil and topography condition of the study area were obtained from soil map and DEM (Digital Elevation Model) map. While, rainfall data was retrieved from rainfall station of Muara Enim. Socio-economic data includes age, education, income, family numbers, distance to water resources, farming business, and water consumption. In-depth interviews and focus group discussions were conducted to collect data related to access of communities to watershed and farming activities.

\section{Data Processing and Analysis}

The land cover map of the study area was established from SPOT 6 imagery year of 2014 analysis using ArcGIS. The classification process was done by supervised classification using Maximum Likelihood Classification Method (MLC) (Ahmad \& Quegan, 2012; Bolstad \& Lillesand, 1991; Gong et al., 2016). The field survey was done in order to clarify the results of interpretation.

Data obtained from the respondents through questionnaires were tabulated and analyzed. The conomic value of hydrological benefits of Perapau subwatershed which includes water values for household and agriculture purposes is estimated using the procurement cost method which is a modification of the travel cost method and the contingent valuation method. This method can be used to determine the economic value of hydrological benefits of the watershed through Willingness to Pay (WTP) from individuals utilizing hydrological services of the Perapau subwatershed (Hufschmidt et al., 1983; Nurfatriani \& Handoyo, 2007; Ulya et al., 2014).

The procurement cost of water is estimated through the expenditure of time and other sacrifices incurred in order to consume water for both household and agriculture purposes. Considering that in the research location the hydrological value of Perapau Subwatershed has not market value yet, economic value is obtained by estimating the average value of WTP.

The WTP value of water for household and agricultural purposes is estimated by regression analysis of the relation between water consumption for household and agriculture purposes with socioeconomic variables that are allegedly influencing the water consumption. The socioeconomic variables that are allegedly influencing the consumption of water for household purposes (Y) are the cost of water procurement for household purpose (X1), household income (X2), age (X3), education (X4), number of family members (X5), and distance to water sources (X6) (Carson \& Mitchell, 1993; Nurfatriani \& Handoyo, 2007; Ulya et al., 2014; Widada \& Darusman, 2004). The relationship between water consumption for households with allegedly influencing variables can be formulated as follows: $\mathrm{Y}=\mathrm{f}(\mathrm{X} 1, \mathrm{X} 2, \mathrm{X} 3, \mathrm{X} 4, \mathrm{X} 5, \mathrm{X} 6)$.

Water consumption for agriculture in the Perapau subwatershed is reflected by the area of paddy field harvest (Y), that estimated to be influenced by the cost of water procurement for agriculture, i.e. the costs incurred to drain water into rice fields (X1), household income (X2), age (X3), education (X4), number of family members (X5), distance to water source (X6) and harvest frequency (X7) (Berbel, Mesa-Jurado, \& Pistón, 2011; Nurfatriani \& Handoyo, 2007; Ulya et al., 2014; Widada \& Darusman, 2004). The relationship between water consumption for agriculture with allegedly influencing variables can be formulated as follows: $\mathrm{Y}=\mathrm{f}(\mathrm{X} 1, \mathrm{X} 2, \mathrm{X} 3, \mathrm{X} 4, \mathrm{X} 5, \mathrm{X} 6)$. The relationship 


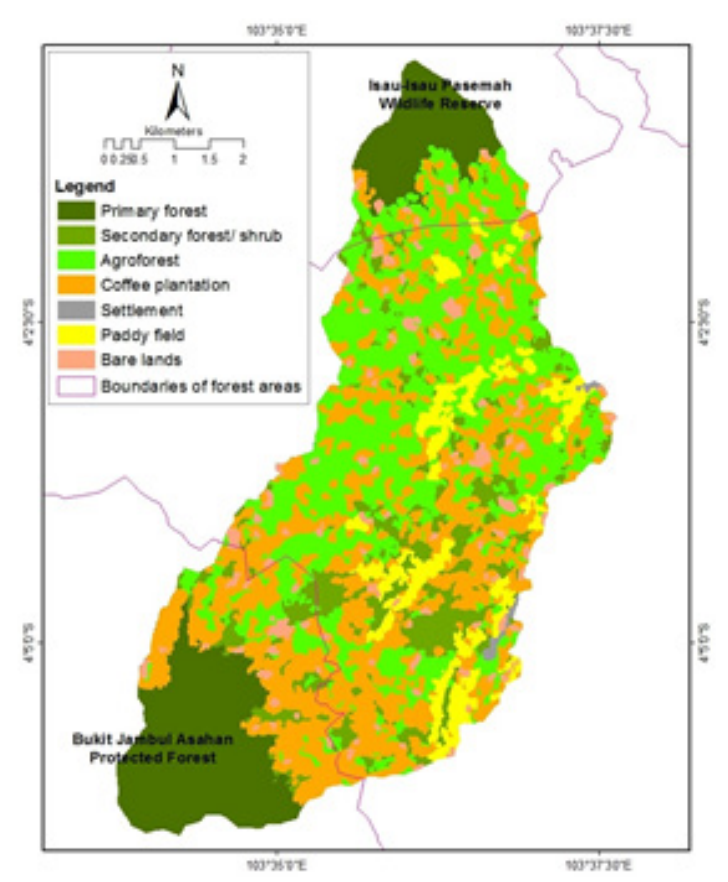

Figure 2. Land cover year of 2014

Table 1. Land cover in Perapau sub watershed

\begin{tabular}{lll}
\hline Land cover & Hectares (ha) & Percent (\%) \\
\hline Primary Forest & 709.21 & 18.08 \\
Secondary forest/ & 459.65 & 11.72 \\
Shrub & & \\
Agro forest & $1,287.53$ & 32.82 \\
Coffee plantation & $1,094.58$ & 27.90 \\
Settlement & 11.79 & 0.37 \\
Paddy field & 233.66 & 5.94 \\
Bare lands & 127.24 & 3.24 \\
\hline
\end{tabular}

between the variables expressed in the best regression equation reflects the WTP of respondents to keep their utilities constant in consuming water for household and agricultural needs. The value of WTP of all respondents reflects the economic value of water for households and agriculture from the Perapau subwatershed.

\section{Result and Discussion}

\section{The condition of the Perapau sub watershed}

The Perapau subwatershed is located in Bukit Barisan Mountains located in the western part of Sumatra Island. The altitude is varied from 596 to 1,595 MSL. Topographical condition classified as moderate to steep slope (16-55\%). The average annual rainfall is 2,822.6 mm/year (2005-2014) with average monthly rainfall of $111.91 \mathrm{~mm}-427.84 \mathrm{~mm}$, average air temperature is $22-24^{\circ} \mathrm{C}$ and the average humidity is $84 \%$ (Badan Pusat Statistik Kabupaten Muara Enim, 2016). The soil type is dominated by ultisol. Analysis of land cover image and land cover data in Perapau subwatershed is presented in Figure 2 and Table 1.
Table 2. Number and land cover of protected forest and wildlife reserve within Perapau subwatershed

\begin{tabular}{lrl}
\hline $\begin{array}{l}\text { Forest area/ } \\
\text { Land cover }\end{array}$ & Hectares (ha) & Percent (\%) \\
\hline $\begin{array}{l}\text { Protected forest } \\
\text { (PF) }\end{array}$ & 972,83 & \\
Secondary & & \\
forest/ shrub & 88,67 & 9.11 \\
Primary forest & 483,01 & 49.65 \\
Agroforest & 97,46 & 10.02 \\
Coffee planta- & 279,25 & 28.10 \\
tion & & \\
Bare lands & 24,44 & 2.51 \\
Wild reserve & 415,54 & \\
(WR) & & \\
Secondary & 8,61 & 2.07 \\
forest/ shrub & & \\
Primary forest & 226,20 & 54.44 \\
Agroforest & 121,10 & 29.14 \\
Coffee planta- & 48,78 & 11.74 \\
tion & & \\
Paddy field & 1,16 & 0.28 \\
Bare lands & 8,68 & 2.09 \\
\hline
\end{tabular}

Land cover of Perapau subwatershed is dominated by plantation, mainly for coffee plantation and agroforest (consist of mix plants such as Durio Zibethinus, Theobroma cacao, Archidendron pauciflorum, and Parkia speciosa). One area of primary forest extends along south part of subwatershed in an altitude of 1000-1490 MSL which is part of Bukit Jambul Asahan protected forest $(\mathrm{PF})$. While another primary forest area is located in the north part of sub watershed that is part of Isau Isau Pasemah Wildlife Reserve (WR). Those two areas of pristine forests estimated covers $18.08 \%$ of the total area of Perapau subwatershed.

Overlay analysis between land cover map and map of forest area (Law no 454/ 2016) shows that the area of Bukit Jambul Asahan PF which is included in Perapau subwatershed is about 972.83 ha. Among this, about 279.25 ha $(28.10 \%)$ has been converted into a coffee plantation and 97.46 ha (10.02\%) for agroforest. This condition also occurred in Isau Isau Pasemah WR, in which forest area that has been converted into coffee plantation and agro forest is about 48.78 ha (11.74\%) and 121.10 ha $(29.14 \%)$ respectively.

Forest conversion in upstream of watersheds will disrupt the role of forests in hydrological balance. In the future, it will threat the continuity of water supply to the communities for both quantity and quality. Forest conversion into other land use becomes the main cause of deforestation in the study area. The forest area in the Perapau subwatershed covers about $18.08 \%$ of the total number of sub watershed. Based on Forestry Law No.41/1999, the forest area within each watershed 
is at least covers $30 \%$ of the watershed. Rusdiana \& Ghufrona (2011) state that forest area less than 30\% in a watershed indicate the damage of upstream watershed which is causes to natural disasters such as floods and landslides.

\section{Characteristics of respondents}

The research respondents are the head of household utilizing water in the Perapau subwatershed to fulfill the household needs. Age of respondents is between 26 to 62 years old with an average age of 43 years old. Respondents' education varies between elementary school, junior high school and high school, most of them are educated up to the junior high school level. Generally, respondents are farmers (98\%) with the average income of respondents is 118.0188 USD. The number of dependent family members is generally 4 to 5 persons per family. The distance between houses to water sources for household needs ranges from 2 to 300 meters with an average distance of 75 meters.

Socioeconomic condition of the community in the Perapau subwatershed

Population density in the four villages is 82 people per $\mathrm{km}^{2}$. SDL subdistrict is located in the highlands of the Bukit Barisan Mountains. Agriculture both paddy fields and dry land farms are the main sources of income. Coffee plantations are wider than the land used for paddy fields. All paddy fields in the study area are irrigated paddy field (Badan Pusat Statistik Kabupaten Muara Enim, 2016). Several studies (Martin, Suhardjito, Darusman, Sunito, \& Winarno, 2016; Waluyo, Ulya, Kunarso, \& Syahbana, 2016) also indicate that people in the research area (Semende tribes) are traditionally rice and coffee farmers. The Semende recognizes the importance of upstream forests that are the source of irrigated paddy fields.

The Semende realize that rice cultivation requires water availability and water management for irrigation. This awareness has been going on for generations and becomes a local institutionalized traditional ecological knowledge. Martin et al. (2016) and Waluyo et al. (2016) added there are some rules in Semende tribe such as the prohibition to convert forests in the upstream irrigation for agricultural land, but people may use timber limited for household purposes. Head of an ataghan (paddy field

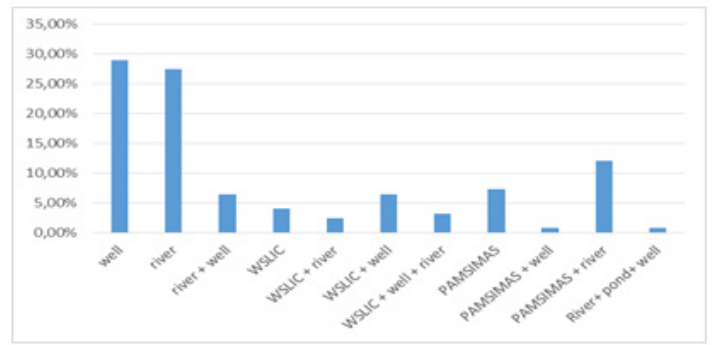

Figure 3. Distribution of household water sources in the study sites (Source: research data) unit) has the power to prohibit to cut down the forests in the upstream of the irrigation canal. The traditional ecological knowledge of the Semende tribe is actually able to protect the existence of forests as upstream of the watershed. However, this mechanism does not work for areas around research sites that not been handled by generations of the Semende. The Semende also cannot prevent farmers from non-Semende tribal groups enter the forest (Martin et al., 2016).

The inclusion of non-Semende tribe into the Perapau subwatershed, especially in Bukit Jambul Asahan PF and Isau Isau Pasemah WS to carry out logging activities, dryland farming and paddy fields became one of the drivers of reduced forest cover in the upper Perapau subwatershed. This long term pressure will threaten the sustainability of the water supply from forests in the upper watershed to irrigating paddy fields. For the Semende tribe, this also means a threat to identity and survival.

\section{Utilization of water for household use in the Perapau subwatershed}

People in the study area obtained water to meet household needs from several sources which are wells, rivers, water pipe system built by WSLIC projects, PAMSIMAS and tebat (pond). The description of water sources for household needs at the study sites is presented in Figure 3.

People generally use water from various water sources to fulfill household needs. There are $29.3 \%$ of which use wells as a source of household water, and $27.4 \%$ use river water. Water obtained from wells, WSLIC and PAMSIMAS system are stored in a home reservoir before being used for bathing, cooking, and washing. People who use water from the river usually do the activities of bathing, washing, and latrines in the river. Water for WSLIC comes from the spring that flowed into the water distribution point and then flowed to houses using pipes and hoses. PAMSIMAS system is sourced from the river (Bulu Kapur River, Malawan River, and Betung River) flowed into the community water reservoir, then flowed into the houses by using a plastic hose.

\section{Water Utilization for Agriculture use in the Perapau subwatershed}

Rice farming systems in Tanah Abang and Perapau villages generally use paddy varieties that cultivated twice a year. The length of time per once planting season is 4 months. In rice farming systems, water is used to inundate the paddy fields through out the growing season. Paddy fields are dried when fertilizing and prior to harvesting. Rice farming systems in Penyandingan and Muara Danau village generally use local paddy varieties that cultivated once a year. The length of time one planting season is 5 months 10 days. In this system, water is used to overwhelm the paddy fields through out the growing season. Paddy fields are dried during 
fertilization (for 2 until 3 days) and before harvesting. Watering is not used in the coffee plantation.

The community gives to consume water for agriculture is higher than the sacrifice required to obtain water for agriculture. Water for agricultural irrigation flows from a water source in the form of a river to an irrigation channel which the Semende called as a siring. Siring is a permanent irrigation channel built by the community independently from the early 1900s. In order to maintain the siring, the people in the research site work together (gotong royong) from the beginning of the irrigation canal (babakan), along with the siring until the water gate in the paddy field (tanggam).

\section{Economic Value of Water for Household}

The best regression equation that states the relationship between the consumption of water for domestic use $(\mathrm{Y})$ with socioeconomic variables that are considered influence is as follows:

$\mathrm{Y}=42.7-0.00000025 \mathrm{X} 1-2.44 \mathrm{X} 5-0.00682 \mathrm{X} 6$ (1)

Where:

$\mathrm{Y}=$ consumption of water for household use (m3/person/year)

$\mathrm{X} 1$ = cost of water supply for household use (USD/m3)

$\mathrm{X} 5$ = number of family members (people)

$\mathrm{X} 6$ = distance to water source (meters)

Equation (1) significant $(\mathrm{P}=0.000)$ with determination coefficient value of $85.2 \%$. This value provides information that $85.2 \%$ of the diversity occurring in the consumption of water for domestic purposes is influenced by the cost of water supply for household use, the number of family members and the distance to the water source. Household income, age, and education do not affect the consumption of water for household purposes in the Perapau subwatershed.

Water consumption for household use is negatively correlated to the cost of water procurement. It means that the greater the cost of water supply for household use, the consumption of water per person decreases. This is in accordance with economic theory, when prices are increasing the demand will decrease. The number of family members is also negatively correlated with the consumption of water for household purposes. Water for domestic purposes is obtained by visiting water

Table 3. The economic value of water for household purposes in the Perapau subwatershed

\begin{tabular}{lrrr}
\hline $\begin{array}{l}\text { Economic } \\
\text { value }\end{array}$ & $\begin{array}{l}\text { Sample } \\
\text { (USD/ } \\
\text { household/ } \\
\text { year) }\end{array}$ & $\begin{array}{l}\text { Population } \\
\text { (house- } \\
\text { hold) }\end{array}$ & $\begin{array}{l}\text { Total value } \\
\text { (USD/ year) }\end{array}$ \\
\hline $\begin{array}{l}\text { Willingness } \\
\text { to pay }\end{array}$ & 156,608 & 823 & $128,905,474$ \\
$\begin{array}{l}\text { Paid Value } \\
\begin{array}{l}\text { Surplus } \\
\text { Consumer }\end{array}\end{array}$ & 452 & 823 & 372.040 \\
Source: Data Processing & 823 & $117,451,121$ \\
\hline
\end{tabular}

sources (river, pond) or flowing from water sources (wells, WSLIC, PAMSIMAS). There is the limited water supply for use in a household, so with the increasing number of family members, the consumption of water for household use will decrease further. Distance to water sources has a negative correlation with water consumption for households. The further distance to the water source, the water consumption will also decrease. The ability of water supply for household purposes will decrease as the distance required to obtain water for household purposes.

The result of data processing with Equation (1) shows that the value of WTP every household to be able to consume water for household use at the Perapau subwatershed is 156,608 USD per year with average household consumption volume of $30.38 \mathrm{~m} 3$ per year. The value paid by the community to consume water for a household purpose is 452 USD per year, hence the consumer surplus received by respondents to consume water for household use is 142,692 USD. The economic value of water for household use in the Perapau subwatershed for 4 villages is 128,905 million USD (Table 3).

A very large consumer surplus value indicates that the value paid by respondents is still very low when compared to the value that should be paid. It indicates that the economic value of hydrological benefits of forests in the catchment area of the Perapau subwatershed is very high, while the rewards for these benefits have not been commensurate with the benefits provided. The low value paid by the respondents is caused by the low sacrifices required to obtain water to provide household needs. The community uses a bucket to collect water in a river or pond and store it in water storage. Communities that obtain water through wells, WSLIC and PAMSIMAS system only need a hose or pipe, a home reservoir (tank, tub) and a water pump machine. Treatment of the equipment used can be said to be minimal or even not treated at all.

\section{The Economic Value of Water for Agriculture}

The best regression equation that states the relationship between the areas of harvest paddy fields per year (Y) with the socioeconomic variables that are suspected of influencing are as follows:

$\mathrm{Y}=-0.0034-0.00000002 \mathrm{X} 1+1.09 \mathrm{X} 7$

Where:

$\mathrm{Y}=$ area of harvest paddy fields per year (ha)

$\mathrm{X} 1=$ cost of water supply for agriculture (USD/year)

$\mathrm{X} 7=$ harvest frequency per year (times)

Equation (2) significant $(\mathrm{P}=0.000)$, the value of the coefficient of determination of $81.1 \%$ which reflects the diversity of area of harvest paddy fields per year in the Perapau subwatershed influenced by the cost of water procurement for agriculture and harvest frequency. The area of harvested paddy fields in the Perapau 
Table 4. The economic value of water for agriculture in the Perapau subwatershed

\begin{tabular}{llll}
\hline $\begin{array}{l}\text { Economic } \\
\text { Value }\end{array}$ & $\begin{array}{l}\text { Sample } \\
\text { (USD/ } \\
\text { household/ } \\
\text { year) }\end{array}$ & $\begin{array}{l}\text { Farmer } \\
\text { Population } \\
\text { (house- } \\
\text { hold) }\end{array}$ & $\begin{array}{l}\text { Total Value } \\
\text { (USD/year) }\end{array}$ \\
\hline $\begin{array}{l}\text { Willing- } \\
\text { ness to pay }\end{array}$ & 1,032 & 807 & 832,187 \\
$\begin{array}{l}\text { Paid Value } \\
\text { Consumer } \\
\text { Surplus }\end{array}$ & 932 & 807 & 140,049 \\
\hline
\end{tabular}

subwatershed is not affected by household income, age, education, number of family members and distance to the water sources.

The area of paddy harvest (Y) is negatively correlated to the cost of water procurement for agriculture (X1). This negative coefficient indicates that the greater the cost of water procurement for agriculture, the lower the consumption of water per harvested area. The harvested area reflects the consumption of water for agriculture, the wider harvested land the more the water is used. The cost of water procurement reflects the sacrifice to flow water into the rice paddy fields. It is in line with the economic theory that the higher the price of an item, the lower the consumption of it. The harvested area of paddy field describing the water consumption for agriculture is positively correlated to the harvest timefrequency per year, that is, by increasing the frequency of harvest, the water consumption will increase. Farmers who cultivated 2 times a year of harvesting period will consume water higher than they did it once a year for the same area.

Based on equation (2), the value of WTP of the respondent to be able to consume water for agriculture is 1,032 USD per hectare with the average harvest area of 1.25 hectares per year. The value paid by the respondent is 174 USD so that the consumer surplus received is 932 USD. The economic value of water for agriculture in the Perapau subwatershed for agriculture is 832,187 USD (Table 4). The values presented in Table 4 provide information that the hydrological benefits of the Perapau subwatershed in the form of water for agriculture are currently still undervalued.

Conversion of forest area into agriculture is one of the causes of deforestation. Conversion of forest areas into agriculture land occurs because of the assumption that the cultivation of agriculture provides benefits directly perceived benefits by society, in the form of monetary benefit from agricultural commodities traded in the market. While the hydrological benefits of forests are not traded on the market so that the public assumes that the hydrological benefits of the Perapau subwatershed have no economic value.

The results of this study provide information that the hydrological benefits of Perapau Subwatershed which includes the economic value of water for household and agricultural purposes amounted 128.9 million USD and 832,187 million USD. The economic value of the hydrological benefits of the Perapau Subwatershed shows the importance of Perapau subwatershed for the community. This should be communicated to the community both for The Semende and non-Semende. Since some upstream of watersheds are protected forests and wildlife reserves, their management is under the responsibility of the government. Information about the economic value of hydrological benefits of forest in upper Perapau subwatershed can be used as one of the reference materials for awareness about forest conservation as a life support system.

\section{Conclusion}

Information about the economic value of environmental services hydrological benefits of Perapau subwatershed shows that forests in the upper watershed provide hydrological benefits which have high economic value. While the community has not understood yet about those value. Information about the economic value of benefits of forest resources (such as hydrological benefits) should be used as a reference in forest area management, especially with the buffer function of living systems which experienced by encroachment or conversion. aspects.

\section{Acknowledgment}

The author thanks the Head of Forestry and Environment Research and Development Institute (FOERDI) of Palembang, Head of Technical Unit of Forestry Service Unit (UPTD) Forestry Semende; and villagers in Muara Danau Village, Penyandingan Village, Tanah Abang Village and Perapau Village for all their support, whether in the form of funding, permits, information, and technical assistance during research activities. We would also like to thank anonymous reviewers for their constructive review which to improve our manuscript. In this article, Nur Arifatul Ulya is the main contributor for natural resources economic aspects, Adi Kunarso is the main contributor for biophysical aspects and Efendi Agus Waluyo is the main contributor for social economic aspects.

\section{References}

Adger, W. N., Brown, K., Cervigni, R., \& Moran, D. (2010). Total Economic Value in Mexico of Forests. Ambio, 24(5), 286-296.

Admiraal, J. F., Wossink, A., de Groot, W. T., \& de Snoo, G. R. (2013). More than total economic value: How to combine economic valuation of biodiversity with ecological resilience. Ecological Economics, 89, 115-122. https:// doi.org/10.1016/j.ecolecon.2013.02.009.

Ahmad, A., \& Quegan, S. (2012). Analysis of Maximum Likelihood Classification on Multispectral Data. Applied Mathematical Sciences, 6(129), 6425-6436. https://doi. org/10.12988/ams.2013.34214.

Badan Pusat Statistik Kabupaten Muara Enim. (2016). Kecamatan Semende Darat laut Dalam Angka Tahun 2016. Muara Enim: Badan Pusat Statistik Kabupaten 
Muara Enim.

Bateman, I. J., Mace, G. M., Fezzi, C., Atkinson, G., \& Turner, K. (2011). Economic analysis for ecosystem service assessments. Environmental and Resource Economics, 48(2), 177-218. https://doi.org/10.1007/s10640-0109418-x.

Berbel, J., Mesa-Jurado, A., \& Pistón, J. M. (2011). Value of Irrigation Water in Guadalquivir Basin (Spain) by Residual Value Method. Water Resources Management, 25(6), 1565-1579. https://doi.org/10.1007/s11269-0109761-2

Bolstad, P. V, \& Lillesand, T. M. (1991). Rapid maximum likelihood classification. Photogrammetric Engineering and Remote Sensing, 57(1), 67-74. Retrieved from http://cat.inist.fr/?aModele=afficheN\&cpsidt $=19507068$.

Brauman, K. A., Daily, G. C., Duarte, T. K., \& Mooney, H. A. (2007). The Nature and Value of Ecosystem Services: An Overview Highlighting Hydrologic Services. Annual Review of Environment and Resources, 32(1), 67-98. https://doi.org/10.1146/annurev. energy.32.031306.102758

Brookhuis, B. J., \& Hein, L. G. (2016). The value of the flood control service of tropical forests: A case study for Trinidad. Forest Policy and Economics, 62, 118-124. https://doi.org/10.1016/j.forpol.2015.10.002

Brown, G. (2013). The relationship between social values for ecosystem services and global land cover: An empirical analysis. Ecosystem Services, 5, 58-68. https://doi. org/10.1016/j.ecoser.2013.06.004

Carson, R. T., \& Mitchell, R. C. (1993). The Value of clean water: The public's willingness to pay for boatable, fishable, and swimmable quality water. Water Resources Research, 29(7), 2445-2454. https://doi.org/10.1029/93WR00495

Carvalho-Santos, C., Honrado, J. P., \& Hein, L. (2014). Hydrological services and the role of forests: Conceptualization and indicator-based analysis with an illustration at a regional scale. Ecological Complexity, 20, 69-80. https://doi.org/10.1016/j.ecocom.2014.09.001

Costanza, R., D’Arge, R., de Groot, R., Farber, S., Grasso, M., Hannon, B., ... van den Belt, M. (1998). The value of the world's ecosystem services and natural capital. Nature, 387(6630), 253-260. https://doi.org/10.1038/387253a0

Costanza, R., Kubiszewski, I., ERvin, D., Bluffstone, R., Boyd, J., Brown, D., ... Yeakly, A. (2011). Valuing ecological systems and services. F1000 Biology Reports, 3(July), 1-6. https://doi.org/10.3410/B3-14

Dwiprabowo, H., Djaenudin, D., Alviya, I., \& Wicaksono, D. (2014). DINAMIKA TUTUPAN LAHAN: Pengaruh Faktor Sosial Ekonomi. (I. Las \& Y. Rahayu, Eds.), PT Kanisius, Yogyakarta, Indonesia. Yogyakarta: PT. Kanisius.

Gong, W., Yuan, L., Fan, W., Wang, X., Stott, P., Env, N., \& Tech, P. (2016). Comparison to Supervised Classification Modelling in Land Use Cover Using Landsat 8 OLI Data : An Example in Miyun County of North China, 15(1), 6268.

Groot, R. S. de, Brander, L., van der Ploeg, S., Costanza, R., Bernard, F., Braat, L., ... van Beukering, P. (2012). Global estimates of the value of ecosystems and their services in monetary units. Ecosystem Services, 1(1), 50-61. https:// doi.org/10.1016/j.ecoser.2012.07.005

Groot, R. S. de, \& Meer, P. J. van der. (2010). Quantifying and valuing goods and services provided by plantation forests. In J. Bauhus, P. J. van der Meer, \& M. Kanninen (Eds.), Ecosystem Goods and Services from Plantation Forests (pp. 16-42). London: Earthscan.

Hanley, N., Shogren, J., \& White, B. (2013). Introduction to Environmental Economics. New Jersey: Oxford University Press. Retrieved from https://books.google. com/books?hl=en\&lr=\&id=Zu0_FjaZqn8C\&pgis $=1$
Hufschmidt, M. M., David E. James, Meister, A. D., Bower, B. T., \& Dixon, J. A. (1983). Environment, natural systems , and development: an economic valuation guide (3rd ed.). Baltimore: John Hopkins University Press.

Kaimowitz, D., \& Angelsen, A. (1998). Economic models of tropical deforestation: a review. Bogor: Center For International Forestry Research. https:/doi. org/10.17528/cifor/000341

Kaldellis, J. K. (2007). The contribution of small hydro power stations to the electricity generation in Greece : Technical and economic considerations. Energy Policy, 35, 21872196. https://doi.org/10.1016/j.enpol.2006.06.021

Martin, E., Suhardjito, D., Darusman, D., Sunito, S., \& Winarno, B. (2016). Tunggu Tubang and Ulu-Ayek: Social Mechanism of Sustainable Protected Forest Management. JMHT, 22(2), 85-93. https://doi. org/10.7226/jtfm.22.2.85

Millennium Ecosystem Assessment. (2005). Living Beyond Our Means: Natural Assets and Human Well-being. Annual Report. Washington DC. https://doi.org/10.2111/ RANGELANDS-D-13-00013.1

Munasinghe, M. (1992). Environmental economics and valuation in development decision making (Environment Working Paper No. 51). Washigton DC.

Murni, S., Whale, J., Urmee, T., Davis, J., \& Harries, D. (2012). The role of micro hydro power systems in remote rural electrification : a case study in the Bawan Valley, Borneo. In Procedia Engineering (Vol. 49, pp. 189-196). https:// doi.org/10.1016/j.proeng.2012.10.127

Nurfatriani, F., \& Handoyo. (2007). Nilai Ekonomi Manfaat Hidrologis Hutan di DAS Brantas Hulu untuk Pemanfaatan Non-Komersial. Info Sosial Ekonomi, 7(3), 193-214.

Raman, N., Hussein, I., \& Palanisamy, K. (2009). Micro hydro potential in West Malaysia. In ICEE 2009 Proceeding 2009 3rd International Conference on Energy and Environment: Advancement Towards Global Sustainability (pp. 348-359). https://doi.org/10.1109/ ICEENVIRON.2009.5398621

Rusdiana, O., \& Ghufrona, R. R. (2011). Aplikasi Model Optimasi Linear Goals Programming Dalam Menentukan Pola Penggunaan Lahan Optimal. Jurnal Silvikultur Tropika, 2(1), 26-34.

Schaafsma, M., Morse-Jones, S., Posen, P., Swetnam, R. D., Balmford, A., Bateman, I. J., ... Turner, R. K. (2014). The importance of local forest benefits: Economic valuation of non-timber forest products in the eastern Arc mountains in Tanzania. Global Environmental Change, 24(1), 295305. https://doi.org/10.1016/j.gloenvcha.2013.08.018

Singarimbun, M., \& Effendi, S. (2008). Metode Penelitian Survei. Jakarta: Pustaka LP3ES.

Ulya, N. A., Warsito, S. P., Andayani, W., \& Gunawan, T. (2014). Nilai ekonomi air untuk rumah tangga dan transportasi- Studi kasus di desa-desa sekitar hutan rawa gambut Merang Kepayang, Provinsi Sumatera Selatan. Jurnal Manusia Dan Lingkungan, 21(2), 232-238.

Waluyo, E. A., Ulya, N. A., Kunarso, A., \& Syahbana, T. A. A. (2016). Eksistensi Kelembagaan Pengelolaan Air di Sub DAS Perapau (Desa Muara Danau dan Desa Tanah Abang, Kecamatan Semende Darat laut, Kabupaten Muara Enim. In A. H. Lukman, F. Nurfatriani, N. E. Lelana, \& R. D. Djenudin (Eds.), Tata Kelola Hutan untuk Mewujudkan Pembangunan Hijau Sumatera Selatan (pp. 241-248). Palembang: Balai Penelitian dan Pengembangan Lingkungan Hidup dan Kehutanan Palembang.

Widada, \& Darusman, D. (2004). Nilai ekonomi air domestik dan irigasi pertanian: Studi kasus di desa-desa sekitar kawasan Taman Nasional Gunung Halimun. Jurnal Manajemen Hutan Tropika, X(1), 15-27. 
Zorrilla-Miras, P., Palomo, I., Gómez-Baggethun, E., MartínLópez, B., Lomas, P. L., \& Montes, C. (2014). Effects of land-use change on wetland ecosystem services: A case study in the Doñana marshes (SW Spain). Landscape and Urban Planning, 122, 160-174. https://doi.org/10.1016/j. landurbplan.2013.09.013 